\title{
PARENTING IN NEW FAMILY FORMS
}

Susan Golombok

Centre for Family Research

University of Cambridge

United Kingdom

Corresponding author: Golombok, Susan (seg42@cam.ac.uk) 


\section{ABSTRACT}

This paper reviews research on parenting and child development in new family forms including families created by assisted reproductive technologies, same-sex parent families, and families headed by single mothers by choice. The research is examined in the context of the issues and concerns that have been raised regarding these families. The findings not only contest popular assumptions about the psychological consequences for children of being raised in new family forms but also challenge the supremacy of the traditional family. It is concluded that the quality of family relationships and the wider social environment appear to be more influential in children's psychological development and adjustment than are the number, gender, sexual orientation or biological relatedness of their parents. 


\section{INTRODUCTION}

The traditional nuclear family comprising a heterosexual married couple with biologically related children is in decline. Instead, a growing number of children are raised by cohabiting parents, by single parents and by stepparents, with many children moving in and out of different family structures as they grow up. These families are often referred to collectively as "non-traditional families", and result mainly from parental separation or divorce and the formation of new cohabiting or marital relationships. Non-traditional families have been widely studied [1]. The focus of the present paper is on "new families", the term used to refer to family forms that either did not exist or were hidden from society until the latter part of the twentieth century, and that represent a more fundamental shift away from traditional family structures than do non-traditional families formed by relationship breakdown and reformation [2]. These include families created by assisted reproductive technologies involving in vitro fertilization (IVF), egg donation, donor insemination, embryo donation and surrogacy, as well as lesbian mother families, gay father families and single mothers by choice. This paper will focus on parenting in "new" rather than "non-traditional" families.

\section{FAMILIES CREATED BY ASSISTED REPRODUCTIVE TECHNOLOGIES}

Since the birth of the first baby through in vitro fertilization [IVF] in 1978 [3], more than 5 million children have been born through assisted reproductive technologies [4]. IVF involves the fertilization of the mother's egg with the father's sperm in the laboratory and the transfer of the resulting embryo(s) to the mother's womb. Although IVF has attracted much publicity, assisted reproduction involving reproductive donation, i.e. the donation of gametes (sperm or eggs), embryos, or the hosting of a pregnancy for another woman 
(surrogacy), has had a more fundamental impact on the family. Children born through egg donation lack a genetic link to their mother whereas children born through sperm donation (donor insemination) lack a genetic connection to their father. With embryo donation, both the egg and sperm are donated and neither parent is genetically related to the child.

Surrogacy involves a woman hosting a pregnancy for another woman and the children lack a gestational link to their mother. They also lack a genetic link to their mother if the surrogate's egg was used in their conception.

It has often been suggested that the creation of families through reproductive donation may be detrimental to positive family functioning $[5,6]$. In order to investigate the consequences of reproductive donation for parenting and child development, a longitudinal study of families formed by egg donation, donor insemination and surrogacy was initiated at the millennium. Contrary to the concerns that had been raised, the findings indicated more positive parent-child relationships in these families when the children were in their preschool years than in the comparison group of natural conception families, irrespective of the type of reproductive donation used [7-11]. The children themselves showed high levels of psychological adjustment but did not differ from the naturally conceived children in spite of their experience of highly involved parenting. In the middle school years, by which time children show an awareness of biological inheritance $[12,13]$ and of the meaning and implications of the absence of a biological connection to parents [14], the families continued to function well, although the reproductive donation families no longer showed more positive parent-child relationships than did the natural conception families and there was evidence of raised levels of psychological problems among mothers who had not been open with their children about their biological origins [15-17]. By adolescence, mothers in surrogacy families showed less negative parenting and reported greater acceptance of their 
adolescent children and fewer problems in family relationships as a whole compared to gamete donation mothers [18]. Within the gamete donation families, less positive relationships were found between mothers and adolescents in egg donation families than in donor insemination families. Although there were no differences in psychological well-being between adolescents in the different family types, parents who had been open with their children about their origins from an early age had more positive relationships with them at adolescence [19].

In some families created through donor insemination, parents and children search for information about, and desire contact with, their sperm donor [20-22]. This is motivated by curiosity about his characteristics and family background. It is not known, as yet, whether families formed through egg donation are similarly interested in their egg donor. For adolescents born through donor insemination, secure attachment relationships with parents appear to be associated with greater acceptance of their donor conception [23].

\section{FAMILIES WITH SAME-SEX PARENTS}

Studies of parenting by lesbian mothers were initiated in the 1970 s. At that time, it was argued that lesbian mothers would be less nurturing than heterosexual mothers and would show higher rates of psychological disorder, and that their children would develop psychological problems as a result. It was also thought that the children of lesbian mothers would show atypical gender development such that boys would be less masculine in their identity and behavior, and girls less feminine, than boys and girls from heterosexual homes. Although the initial studies were prompted by custody disputes involving lesbian mothers, similar concerns have been raised in relation to lesbian women becoming mothers through adoption and by donor insemination. 
There is now a large body of research showing that lesbian mothers are just as likely to have good mental health and to have positive relationships with their children as are heterosexual mothers, and that their children are no more likely to show adjustment difficulties, poor performance at school or atypical gender-role behavior than are children with heterosexual parents [24-26]. These findings have been replicated in general population samples [24-31] and have also been confirmed through meta-analyses [32, 33].

The circumstances of gay fathers are somewhat different from those of lesbian mothers in that it is rare for fathers, whether heterosexual or gay, to be primary caregivers. Although research on fathering has shown that the constructs of fathering and mothering, involving positive engagement, warmth and responsiveness, are largely the same, and that heterosexual fathers influence their children in similar ways to mothers [34], fathers are generally believed to be less suited to parenting than are mothers [35]. Moreover, gay fathers may be exposed to greater stigmatization regarding their sexual identity than are lesbian mothers [36, 37]. Contrary to this viewpoint, a recent study of the brain activity of heterosexual mothers, heterosexual fathers and adoptive gay fathers, all of whom had young babies, found heightened activity in areas of the brain associated with emotion processing in heterosexual mothers and increased activity in areas associated with cognitive processing in heterosexual fathers, whereas the gay fathers showed increased activity in both of these regions [38]. These findings add to the emerging body of evidence that parenting influences brain activity, and suggest that gay fathers who are primary caregivers may respond similarly to both heterosexual mothers and fathers.

Studies of gay father families have largely focused on families formed through adoption. In a study of the psychological adjustment of 2-year-olds, no differences were 
found between children with gay, lesbian and heterosexual parents [39]. Farr and colleagues [40] found preschool children adopted in infancy by gay fathers to be as well-adjusted as those adopted by lesbian or heterosexual parents. In an observational assessment of family play, the gay couples were rated as less supportive of the other parent, but also as less undermining, than were the heterosexual couples [41]. In a comparison of adoptive gay father, lesbian mother and heterosexual parent families with 3-9-year-old children, the differences identified between family types indicated more positive parental wellbeing and parent-child relationships, and lower levels of children's externalizing problems, in gay father families [42]. As stability and continuity of care are widely accepted to be prerequisites of children's secure attachment relationships with parents, it is noteworthy that adoptive gay fathers were less likely to dissolve their relationship in the first 5 years of parenthood than were comparison groups of lesbian and heterosexual adoptive couples [43].

In recent years, the focus has turned from comparisons between same-sex and heterosexual parent families to the study of variation within same-sex parent families, particularly to the influence of parenting on children's adjustment. The psychological wellbeing of same-sex parents including the quality of the couple's relationship, the quality of parenting experienced by children and stigmatization of the family have all been associated with children's psychological adjustment. For example, higher levels of parenting stress and lower levels of parental relationship quality were found to be associated with higher levels of children's behavioral problems in lesbian mother families [44] and parental depression, relationship conflict and lack of preparation for the adoption were associated with children's emotional and behavioral problems in both lesbian mother and gay father 
families [39]. In contrast, adolescents who had positive relationships with their same-sex parents were more likely to be well-adjusted and functioning well at school $[29,30]$.

Stigmatization of same-sex parent families arising from parents' sexual orientation has been associated with emotional and behavioral problems in children [45-48]. Factors that protect children against the negative effects of stigmatization include contact with other children with same-sex parents, positive relationships with parents, peers and extended family, supportive schools and communities, and legislation that is conducive to the optimal functioning of same-sex parent families [45, 46, 48-50].

Investigations of parenting practices in same-sex parent families have found lesbian and gay parents to share parenting more equally than do heterosexual parents $[26,51]$. In terms of relationship breakdown, lesbian and gay parents appear to show similar rates of separation to heterosexual parents [52]. Although same-sex parents are involved in their children's schools, their level of involvement appears to be dependent on their acceptance by other parents [53].

Regarding the use of assisted reproduction, a study of lesbian mother families formed through donor conception found mothers to be generally satisfied with their choice of a known, identifiable or anonymous sperm donor, with no differences in adolescent adjustment according to the type of donor used [54]. A qualitative study of young adults conceived using known sperm donors identified variation in how the donor was perceived; some viewed him strictly as a donor and not as a member of their family, others saw him as a member of their extended family but not as a parent, and yet others saw him as a father [55]. In the first study of parenting in gay father families formed through surrogacy and egg donation [56], gay fathers showed high levels of parenting quality. Similar to the finding of 
Farr \& Patterson [41], gay fathers and their children showed some differences in dyadic interaction in comparison to lesbian mother families.

\section{SINGLE MOTHERS BY CHOICE}

Parental divorce or separation is the most common reason for children to be raised in single-mother families and there has also been a rise in the number of children born to single unmarried mothers as a result of unplanned pregnancies. Both of these types of single-mother family have been associated with raised levels of parenting difficulties [57, 58]. However, an increasing number of single women are choosing to parent alone and have children through donor insemination. These mothers, often referred to as "single mothers by choice" or "solo mothers", have not experienced marital conflict and are less likely to have experienced the economic hardship or psychological problems that commonly result from marital breakdown and unplanned single parenthood. Nevertheless, their children often grow up not only without a father but also without knowing the identity of their sperm donor. There is little research on this new family form. However, a comparison between solo mother families and two-parent families, all with donor-conceived children, found no differences in parenting quality apart from lower mother-child conflict in solo mother families [58]. Although the children in solo mother and two-parent families did not differ in psychological adjustment, parenting stress and financial difficulties were associated with children's psychological difficulties in both family types.

\section{CONCLUSIONS}

The findings of the studies reviewed above show that new family forms are characterized by positive parenting and well-adjusted children. This is perhaps not surprising as the children were much-wanted by their parents and, by necessity, planned. From a theoretical 
perspective, what these studies tell us is that the number, gender, sexual orientation and biological relatedness of parents to their children are less influential in children's psychological development than are family processes such as the quality of family relationships and the social environment in which the children are raised (see Figure 1). Future research would benefit from less reliance on self-report measures and greater use of observational, neurobiological, and digital ambulatory approaches to the assessment of child development and parent-child relationships in new family forms. 


\section{Conflict of interest statement}

Nothing declared

\section{Acknowledgement}

This work was funded by a Wellcome Trust Senior Investigator Award [097857/Z/11/Z] 


\section{References}

1. Golombok, S., \& Tasker, F. (2015). Socio-emotional development in changing family contexts. In R. M. L. (Series Ed.) \& M. E. Lamb (Vol. Ed.), Handbook of child psychology and developmental science: Vol. 3. Social, emotional and personality development (7th ed.). Hoboken, NJ: Wiley.

2. Golombok, S. (2015). Modern Families. Cambridge: Cambridge University Press.

3. Steptoe, P. C., \& Edwards, R. G. (1978). Birth after the reimplantation of a human embryo. The Lancet, 1978-1978.

4. Adamson, D. (2012). ICMART world reporting: Preliminary 2008 data. 28th ESHRE Annual Conference, Istanbul.

5. Cahn, N. (2009). Old lessons for a new world: Applying adoption research and experiences to assisted reproductive technology. New York: Eban B. Donaldson Adoption Institute.

6. Feast, J. (2003). Using and not losing the messages from the adoption experience for donor-assisted conception. Human Fertility, 6(1), 41-45.

7. Golombok, S., Jadva, V., Lycett, E., Murray, C., \& MacCallum, F. (2005). Families created by gamete donation: Follow-up at age 2. Human Reproduction, 20(1), 286293.

8. Golombok, S., Lycett, E., MacCallum, F., Jadva, V., Murray, C., Rust, J., et al. (2004). Parenting infants conceived by gamete donation. Journal of Family Psychology, 18(3), 443-452.

9. Golombok, S., MacCallum, F., Murray, C., Lycett, E., \& Jadva, V. (2006). Surrogacy families: Parental functioning, parent-child relationships and children's psychological development at age 2. Journal of Child Psychology and Psychiatry, 47(2), 213-222.

10. Golombok, S., Murray, C., Jadva, V., Lycett, E., MacCallum, F., \& Rust, J. (2006). Nongenetic and non-gestational parenthood: Consequences for parent-child relationships and the psychological well-being of mothers, fathers and children at age 3. Human Reproduction, 21(7), 1918-1924.

11. Golombok, S., Murray, C., Jadva, V., MacCallum, F., \& Lycett, E. (2004). Families created through surrogacy arrangements: Parent-child relationships in the 1st year of life. Developmental Psychology, 40(3), 400-411.

12. Gregg, E., Solomon, A., Johnson, S. C., Zaitchik, D., \& Carey, S. (1996). Like father, like son: Young children's understanding of how and why offspring resemble their parents. Child Development, 67, 151-171.

13. Williams, J. M., \& Smith, L. A. (2010). Concepts of kinship relations and inheritance in childhood and adolescence. British Journal of Developmental Psychology, 28(3), 523-546.

14. Brodzinsky, D. M. (2011). Children's understanding of adoption: Developmental and clinical implications. Professional Psychology: Research and Practice, 42(2), 200-207.

15. Golombok, S., Readings, J., Blake, L., Casey, P., Marks, A., \& Jadva, V. (2011). Families created through surrogacy: Mother-child relationships and children's psychological adjustment at age 7. Developmental Psychology, 47(6), 1579-1588.

16. Golombok, S., Readings, J., Blake, L., Casey, P., Mellish, L., Marks, A., et al. (2011). Children conceived by gamete donation: The impact of openness about donor 
conception on psychological adjustment and parent-child relationships at age 7 . Journal of Family Psychology, 25(2), 230-239.

17. Golombok, S., Blake, L., Casey, P., Roman, G., \& Jadva, V. (2013). Children born through reproductive donation: A longitudinal study of child adjustment. Journal of Child Psychology and Psychiatry, 54, 653-660.

18. Golombok, S., Ilioi, E., Blake, L., Roman, G., \& Jadva, V. (under revision). A longitudinal study of families formed through reproductive donation: Parentadolescent relationships and adolescent adjustment at age 14. Developmental Psychology.

- This paper presents findings at adolescence from the only longitudinal study of parenting in families created by reproductive donation.

19. Ilioi, E., Blake, L., Jadva, V., Roman, G., \& Golombok, S. (under revision). The role of age of disclosure of biological origins in the psychological wellbeing of adolescents conceived by reproductive donation: A longitudinal study from age 1 to age 14 . Journal of Child Psychology and Psychiatry.

20. Freeman, T., Jadva, V., Kramer, W., \& Golombok, S. (2009). Gamete donation: Parents' experiences of searching for their child's donor siblings and donor. Human Reproduction, 24(3), 505-516.

21. Jadva, V., Freeman, T., Kramer, W., \& Golombok, S. (2010). Experiences of offspring searching for and contacting their donor siblings and donor. Reproductive Biomedicine Online, 20(4), 523-532

22. Scheib, J. E., \& Ruby, A. (2008). Contact among families who share the same sperm donor. Fertility \& Sterility, 90(1), 33-43.

23. Slutsky, J., Jadva, V., Freeman, T., Persaud, S., Steele, M., Steele, H., Kramer, W., \& Golombok, S. (2016). Integrating Donor Conception into Identity Development: Adolescents in fatherless families. Fertility and Sterility, 106(1), 202-208.

- This is the first study to examine the relation between security of attachment to parents and acceptance of being donor-conceived.

24. Goldberg, A. (2010). Lesbian and gay parents and their children: Research on the family life cycle. Washington, DC: American Psychological Association.

25. Patterson, C. J. (2009). Children of lesbian and gay parents: Psychology, law, and policy. The American Psychologist, 64(8), 727-736.

26. Patterson, C. J. (2013). Sexual orientation and family lives. In C. J. Patterson \& A. R. D'Augelli (Eds.), Handbook of psychology and sexual orientation. New York: Oxford University Press.

27. Potter, D. (2012). Same-sex parent families and children's academic achievement. Journal of Marriage and Family, 74, 556-571.

28. Wainright, J. L., \& Patterson, C. J. (2006). Delinqency, victimization, and substance use among adolescents with female same-sex parents. Journal of Family Psychology, 20(3), 526-530.

29. Wainright, J. L., \& Patterson, C. J. (2008). Peer relations among adolescents with female same-sex parents. Developmental Psychology, 44(1), 117-126. 
30. Wainright, J. L., Russell, S. T., \& Patterson, C. J. (2004). Psychosocial adjustment, school outcomes, and romantic relationships of adolescents with same-sex parents. Child Development, 75(6), 1886-1898.

31. Rosenfeld, M. J. (2010). Nontraditional families and childhood progress through school. Demography, 47(3), 755-775.

32. Crowl, A., Ahn, S., \& Baker, J. (2008). A meta-analysis of developmental outcomes for children of same-sex and heterosexual parents. Journal of GLBT Family Studies, 4(3), 385-407.

33. Fedewa, A. L., Black, W. W., \& Ahn, S. (2014). Children and adolescents with samegender parents: A meta-analytic approach in assessing outcomes. Journal of GLBT Family Studies, 11(1), 1-34.

34. Fagan, J., Day., R., Lamb, M., \& Cabrera, N. J. (2014). Should researchers conceptualize differently the dimensions of parenting for fathers and mothers? Journal of Family Theory \& Review, 6, 390-405.

35. Biblarz, T. J., \& Stacey, J. (2010). How does the gender of parents matter? Journal of Marriage and the Family, 72(1), 3-22.

36. Goldberg, A. (2010). Goldberg, A. E. (2010). Studying complex families in context. Journal of Marriage and Family, 72(1), 29-34.

37. Goldberg, A. E., \& Smith, J. Z. (2011). Stigma, social context, and mental health: lesbian and gay couples across the transition to adoptive parenthood. Journal of Counseling Psychology, 58(1), 139-50.

38. Abraham, E., Hendler, T., Shapira-Lichter, I., Kanat-Maymon, Y., Zagoory-Sharon, O., \& Feldman, R. (2014). Father's brain is sensitive to childcare experiences. Proceedings of the National Academy of Sciences, 1-6.

39. Goldberg, A. E., \& Smith, J. Z. (2013). Predictors of psychological adjustment in early placed adopted children with lesbian, gay, and heterosexual parents. Journal of Family Psychology, 27(3), 431-42.

40. Farr, R., Forssell, S., \& Patterson, C. (2010). Parenting and child development in adoptive families: Does parental sexual orientation matter? Applied Developmental Science, 14(3), 164-178.

- This study of parenting in adoptive gay father, lesbian mother and heterosexual parent families is based on representative samples of these families.

41. Farr, R., \& Patterson, C. (2013). Coparenting among lesbian, gay, and heterosexual couples: Associations with adopted children's outcomes. Child Development, 84(4), 1226-1240.

42. Golombok, S., Mellish, L., Jennings, S., Casey, P., Tasker, F., \& Lamb, M. E. (2014). Adoptive gay father families: Parent-child relationships and children's psychological adjustment. Child Development, 85(2), 456-468.

43. Goldberg, A., \& Garcia, R. (2015). Predictors of relationship dissolution in lesbian, gay, and heterosexual adoptive parents. Journal of Family Psychology, 29(3), 394404.

44. Chan, R. W., Raboy, B., \& Patterson, C. J. (1998). Psychosocial adjustment among children conceived via donor insemination by lesbian and heterosexual mothers. Child Development, 69(2), 443-457. 
45. Bos, H. M. W., Gartrell, N. K., Peyser, H., \& van Balen, F. (2008). The USA National Longitudinal Lesbian Family Study (NLLFS): Homophobia, psychological adjustment, and protective factors. Journal of Lesbian Studies, 12(4), 455-471.

46. Bos, H., \& Gartrell, N. (2010). Adolescents of the USA National Longitudinal Lesbian Family Study: Can family characteristics counteract the negative effects of stigmatization? Family Process, 49(4), 559-572.

47. Bos, H., Gartrell, N., \& van Gelderen, L. (2013). Adolescents in lesbian families: DSMoriented scale scores and stigmatization. Journal of Gay \& Lesbian Social Services, 25(2), 121-140.

48. van Gelderen, L., Gartrell, N., Bos, H., \& Hermanns, J. (2012). Stigmatization and promotive factors in relation to psychological health and life satisfaction of adolescents in planned lesbian families. Journal of Family Issues, 34, 809-827.

49. Lick, D. J., Tornello, S. L., Riskind, R. G., Schmidt, K. M., \& Patterson, C. J. (2012). Social climate for sexual minorities predicts well-being among heterosexual offspring of lesbian and gay parents. Sexuality Research and Social Policy, 9, 99-112.

50. Patterson, C. J., Riskind, R. G., \& Tornello, S. L. (2014). Sexual orientation and parenting: A global perspective. In A. Abela \& J. Walker (Eds.). Contemporary Issues in Family Studies: Global Perspectives on Partnetships. Parenting and support in a changing world. New York: Wiley/Blackwell.

51. Tornello, S. L., Kruczkowski, S. M., \& Patterson, C. J. (2015). Division of labor and relationship quality among male same-sex couples who became fathers via surrogacy. Journal of GLBT Family Studies, 11(4), 375-394.

52. Goldberg, A., \& Garcia, R. (2015). Predictors of relationship dissolution among lesbian, gay, and heterosexual adoptive couples. Journal of Family Psychology, 29, 394-404.

- Provides important data on the issue of whether lesbian and gay couples with children are more likely to separate than are heterosexual parents and factors associated with relationship breakdown.

53. Goldberg, A., \& Smith, J. Z. (2014). Predictors of school engagement among lesbian, gay, and heterosexual adoptive parents of kindergarteners. Journal of School Psychology, 52, 463-478.

54. Gartrell, N., Bos, H., Goldberg, A., Deck, A., \& van Rijn-van Gelderen, L. (2015). Satisfaction with known, open-identity, or unknown sperm donors: reports from lesbian mothers of 17-year-old adolescents. Fertility and Sterility, 103(1), 242-248.

55. Goldberg, A. E., \& Allen, K. R. (2013). Donor, dad, or ...? Young adults with lesbian parents' experiences with known donors. Family Process, 52(2), 338-350.

56. Golombok, S., Blake, L., Slutsky, J., Raffanello, E., Roman, G., \& Ehrhardt, A. (under revision). Gay father families through surrogacy: Parenting and child adjustment. Child Development.

57. Amato, P. R. (2001). Children of divorce in the 1990s: An update of the Amato and Keith (1991) meta-analysis. Journal of Family Psychology, 15, 355-370.

58. Amato, P. R. (2005). The impact of family formation change on the cognitive, social, and emotional well-being of the next generation. The Future of Children, 15(2), 7596. 
59. Golombok, S., Zadeh, S., Imrie, S., Smith, V., \& Freeman, T. (2016). Single mothers by choice: Mother-child relationships and children's psychological adjustment. Journal of Family Psychology, 30(4), 409-418.

- Presents findings from the largest controlled study to date of parenting by single mothers by choice. 
Figure 1. Conceptual model of bidirectional influences of family structure and family processes on child development. 


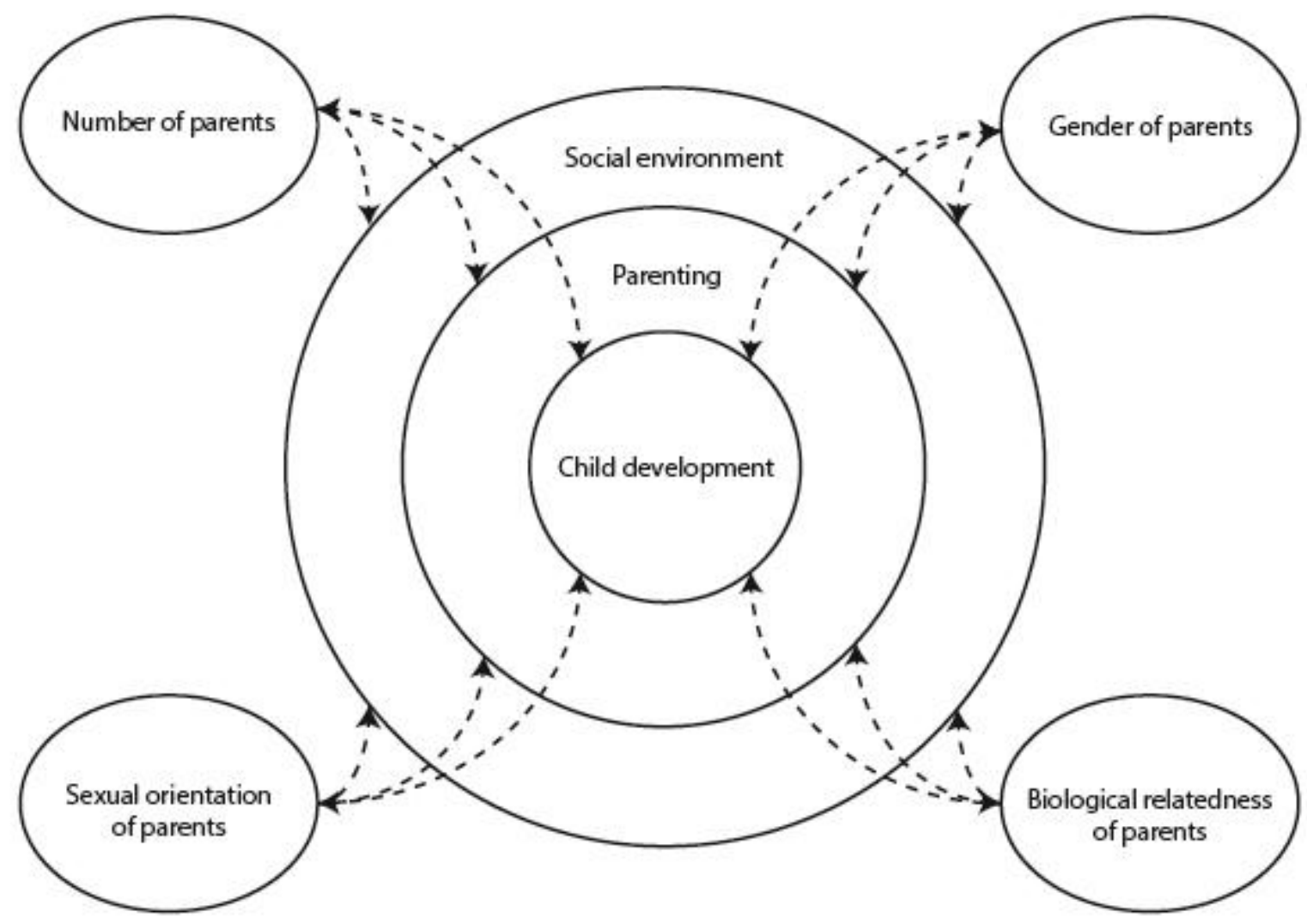

